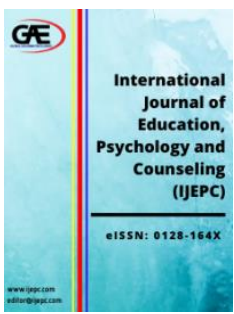

\author{
International Journal of Education, \\ Psychology and Counselling (IJEPC) \\ Journal Website: http://ijepc.com/ \\ eISSN: 0128-164X
}

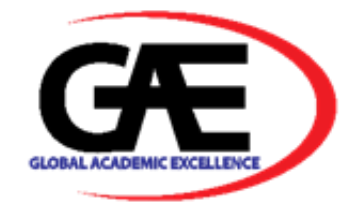

\title{
INVESTIGATING MOTIVATION, EMOTIONAL INTELLIGENCE, WORK SATISFACTION AND ORGANIZATIONS COMMITMENT AMONG PRIMARY SCHOOL ISLAMIC EDUCATION TEACHER
}

\author{
Hujaimah @ Siti Syafiqah Bt Juhumin ${ }^{1}$, Mohamad Nizam Bin Nazarudin ${ }^{2 *}$, Zakiah Binti Noordin ${ }^{3}$, \\ Nur Afny Juati ${ }^{4} \&$ Jumadi Bin Musa ${ }^{5}$
}

1 Rural Education Unit, Faculty of Psychology and Education, Universiti Malaysia Sabah, Kota Kinabalu, Sabah

2 Rural Education Unit, Faculty of Psychology and Education, Universiti Malaysia Sabah, Kota Kinabalu, Sabah

Email: mnizam@ums.edu.my

3 Institut Pendidikan Guru Kampus Gaya, Sabah

Email: zakiahnoordin@gmail.com

4 Rural Education Unit, Faculty of Psychology and Education, Universiti Malaysia Sabah, Kota Kinabalu, Sabah

5 Rural Education Unit, Faculty of Psychology and Education, Universiti Malaysia Sabah, Kota Kinabalu, Sabah

* Corresponding Author

\section{Article Info:}

\section{Article history:}

Received date:02.06.2020

Revised date: 14.06.2020

Accepted date: 15.06 .2020

Published date: 15.06.2020

\section{To cite this document:}

Juhumin, H. S., Nazarudin, M. N.,

Noordin, Z., Juati, N. A., \& Musa, J. (2020). Investigating Motivation, Emotional Intelligence, Work Satisfaction and Organizations Commitment among Primary School Islamic Education Teacher. International Journal of Education, Psychology and Counseling, 5 (35), 225-236.

DOI: $10.35631 /$ IJEPC.5350020.

\begin{abstract}
:
There is evidence indicating that most teachers in most school systems are not satisfied with their jobs. This study aimed to investigate the relationship between Islamic education teacher motivation, emotional intelligence work satisfaction, and organizational commitment in Ranau district primary schools. Furthermore, the study aims to examine the role of gender and age in motivation, emotional intelligence, and work satisfaction. The participants were selected by proportional stratified sampling and simple random selection. This study adopted a survey research design that utilized an ex-post facto research type in which the researcher used questionnaires to collect data from the respondents. The instruments used are the A Questionnaire Measure of Individual Difference in Achieving Tendency (QMAT), Multifactor Emotional Intelligence Scale (MIES), Job in General' (JIG) \& Job Descriptive Index (JDI) and Organization Commitment Questionnaire (OCQ). A total of 108 Islamic Education teachers (mean age $40.1+1.2$ years; 47 males, 61 female) from 71 primary schools in Ranau District were involved in this study. The data gathered from the respondents were downloaded into the Statistical Package for the Social Sciences (SPSS) for quantitative analysis. The results of the study indicate that there is a positive significant relationship between motivation $[r=0.905, p<.05)]$, emotional intelligence $[r=0.912, p<.05)]$, work satisfaction $[\mathrm{r}=0.913, \mathrm{p}<.05)]$ and organizations commitment. It is also found there is no significant difference among primary school teachers of different
\end{abstract}


ages and gender concerning motivation, emotional intelligence work
satisfaction, and organization commitment. The present study gains
significance as the results can assist the teachers and organizations in
enhancing the organizational commitment of teachers.

Keywords:

Motivation, Emotional Intelligence, Work Satisfaction, Organizations Commitment, Primary School, Islamic Education, Teacher

\section{Introduction}

The world of education is facing transformations in line with its position as a key and important medium in the formation of nation generations. Changes in various policies and restructuring in education have taken place. In line with this, the Malaysian Education Development Plan (PPPM) 2013-2025 was launched and is the basis and guide to the holistic Malaysian education system (KPM, 2013). The plan provides a comprehensive development framework for the rapid and sustainable development of the education system until 2025. All of these changes lead to better education equipping each student with new skills, knowledge, critical thinking and creativity, strong leadership skills, effective communication, values, ethics, responsibility and ability to cope with and overcome the challenges of the 21 st century. The change also demands the increased for comprehensive quality management, accountability and organizational effectiveness in schools. Teachers play an important role in ensuring achievement in school (Bai, Piri \& Piri, 2014). The success of the education system is a result of the perseverance and dedication of teachers, administrators and support staff at all levels. Without teacher active involvement, the goal of curriculum transformation in schools is difficult to achieve. The quality of teachers is not only measured in terms of excellence in teaching practice but is also measured by their over time performance in school. Teachers are required to perform the task by the description of the official task assigned. However, a well-functioning school requires its teachers to perform more than the official job description. Excellent teacher behavior is a hallmark of school high performance.

\section{Literature Review}

Teachers are the staff of a large and complex organization. In today's age of globalization, teachers' tasks are increasingly challenging and demanding. Implementing various reforms in education has certainly made teachers' roles and responsibilities bigger, more challenging and complex. Studies show that teachers careers in Malaysia are stressful and that they affect teachers' emotional state (Chua \& Adi, 2002). Teacher heavy responsibilities and assignments challenge the emotional capacity of teachers to trigger various instances of misconduct (Syed Najmuddin et al., 2011). The ever-changing nature of the teacher's work has increased as the community's expectations of the teachers have increased. Teachers face many forms of change, both inside and outside of their profession (Omar \& Khuan, 2005). Among the other problems that exist is the nature of school organization today, which is an obstacle to improving teaching and learning. Besides, it was found that only 12 percent of teachers 'teaching was delivered at high standards, while another 38 percent was at 'satisfactory standards' and 50 percent of 'teaching was dissatisfied' (KPM, 2013). This is evidenced by the report on the achievement of the Khatam Al-Quran Model showing that the number of pupils who are successful in their primary education at the primary school level is small. Table 1 shows statistics summary of the Khatam al-Quran Model for 2017, 2018 and 2019 achievements. Only 1.23 per cent of students succeeded in reciting the Quran until mid-2019. This situation raises the question of whether the commitment of Islamic education teachers in Ranau district is declining. 
Table 1: Achievements of the Khatam Quran Model for 2017, 2018 and 2019

\begin{tabular}{ccccccccccc}
\hline Year & $\begin{array}{c}\text { Student } \\
\text { Total }\end{array}$ & $\begin{array}{ccccc}\mathbf{1} \\
\mathbf{2}\end{array}$ & $\mathbf{2}$ & $\mathbf{3}$ & $\mathbf{4}$ & $\mathbf{5}$ & $\mathbf{6}$ & AlQuran & \multirow{2}{*}{ Khatam } & \multirow{2}{*}{} \\
\hline 2017 & 5330 & 937 & 1089 & 833 & 654 & 360 & 185 & 1217 & 55 & 1.03 \\
2018 & 5501 & 1206 & 935 & 845 & 693 & 395 & 174 & 1219 & 34 & 0.61 \\
2019 & 5690 & 1129 & 1016 & 868 & 778 & 422 & 177 & 1230 & 70 & 1.23 \\
\hline
\end{tabular}

Source: Islamic Education Unit, Ranau District Education Office (2019)

In addition to teaching, teachers also have to deal with administrative management and thus administrative work will be a burden. It will cause emotional disturbance, stress and dissatisfaction among teachers (Mukundan \& Ahour, 2011). Some teachers will stop working if this burden is no longer bearable. As such, the real potential of teachers will sink as they are burdened with tasks that should not be assigned to them. In order to overcome and avoid the above situations, appropriate steps must be taken to ensure that teachers are satisfied with their work and thus committed to the job. The scenario and statistics of the transfer of teachers in this country from one school to another is quite high. The transfer of teachers from Sabah to other states is highest especially in Islamic Education subject teachers. The transfer of a large number of teachers from one school will have certain effects such as the shortage of teachers and the influx of specialists especially teachers who have long been teaching or teachers who have lost the status of district level coaches. Lack of teacher commitment to the organization is also associated with absenteeism or neglect of duty (Jackson, 2018). Surveys conducted in some schools have found that some teachers are often absent for specific reasons (Mukundan \& Ahour, 2011; Surianshah, 2019; Mashaba \& Maile, 2019). Among the reasons identified is attending entrepreneurial courses that prove there are a small number of teachers seeking other sources of income. Whether this is due to a lack of motivation or another reason.

Syafrimen (2004) suggests that the study of emotional intelligence among teachers should be expanded to explore related issues. The level of emotional intelligence of teachers needs to be identified in order to see how it relates to other elements of the work environment, such as organizational commitment. Emotional intelligence is considered important and has a positive relationship with individual task commitment, but that association is often overlooked because task commitment is often associated with job satisfaction (Yahzanon \& Yusof, 2011).

Teacher job satisfaction is an important target in human resource management, as it can influence teacher productivity and performance (Baharin \& Hamiza, 2008). There were complaints of dissatisfaction with the school location. This has led to the issue of job satisfaction in the Ranau district becoming an issue that needs to be addressed. The problems among Islamic education teachers in the Ranau area was the issue of settlements, where those stationed in the rural area often had trouble adjusting to the local environment. This is in addition to issues of housing, school environment and social relations including relationships with employers, staff and the local community.

The question also arises when some teachers are less committed to the school organization. Based on interviews with Islamic Education Head of Unit at PPD, it is evident that some teachers were found to be having problems with their job. These include mistakes such as not preparing a teaching plan, not submitting a teaching plan for review, not performing a formal class as stated in the personal timetable as well as the absence of assignments. These issues are closely linked to the decline in organizational commitment. Therefore, the researcher wants to 
see whether motivation, emotional intelligence and job satisfaction are related to the lack of organizational commitment among Islamic education teachers. Therefore, this study seeks to ascertain the relationship of motivation, emotional intelligence, job satisfaction with the commitment of Islamic education teachers in Ranau district only. This study also examined motivation, emotional intelligence, job satisfaction and organizational commitment by Islamic education teachers by looking at demographic factors such as gender and age.

\section{Research Purpose}

The purpose of this study was to investigate the relationship between motivation, emotional intelligence, work satisfaction and organizations commitment among Islamic Education, Teacher in Ranau District Primary School.

\section{Methods}

\section{Participants}

Islamic Education teachers (mean age $40.1+1.2$ years; 47 males, 61 female) from Ranau district primary school have volunteered to take part as respondent. To determine the sample size from population of 147 Islamic Education teacher, the researcher refers to the determination of sample size tables built by Krejcie and Morgan (1970). A total of 108 respondent were selected at random from 71 primary school in Ranau district. A total of 120 participants were 20 to 30 years $(20.4 \%), 34(31.5 \%)$ were aged 31 to 40 years and $41(38.0 \%)$ were aged 41 to 50 years and $11(10.2 \%)$ were over 51 years (Table 1)

Table 1: Distribution Respondent Ages

\begin{tabular}{lcccc}
\hline & $\mathbf{2 0 - 3 0}$ years & 31-40years & 41-50 Tahun & >50 years \\
\hline Age & $22(20.4 \%)$ & $34(31.5 \%)$ & $41(38.0 \%)$ & $11(10.2 \%)$ \\
\hline $\mathrm{N}=108$ & & &
\end{tabular}

\section{Instrument and Data Analyses}

Questionnaire Measure of Individual Difference in Achieving Tendency (QMAT), Multifactor Emotional Intelligence Scale (MIES), Job in General' (JIG) \& Job Descriptive Index (JDI). and Organization Commitment Questionnaire (OCQ) were simultaneously administered to the Islamic Education teacher in the primary schools involved in this study by the researcher. They were given enough time and instruction to answer these questionnaires. The consents of the teachers and the school authorities were obtained, and the purpose of the study was explained to them before distributing the instruments. All of the questionnaires items were presented in Malay language. To make sure meaning uniformity across the two cultures all of the items were translated from English into Malay and then back translated into English. Two education professors fluent in Malay and English language have evaluated the two translations and the best items were selected for Pilot surveys. Pilot surveys were administrated to a sample of primary school teachers also in Ranau district.

Results demonstrate that translated items were appropriate. After developing the final version, data were collected at regularly planned teacher meetings. In each school, researchers explained the general purpose of the study and assured the confidentiality of all responses. The following instruments were utilized in this study: The coefficient alphas for A Questionnaire Measure of Individual Difference in Achieving Tendency (QMAT), Multifactor Emotional Intelligence Scale (MIES), Job in General (JIG) \& Job Descriptive Index (JDI), and Organization Commitment Questionnaire (OCQ) were .84, .86, .87 and .85 respectively. The 
statistical tests employed in this study were Mean, Standard Deviation, t-test, one-way ANOVA, and Pearson product moment correlation (Table 2).

Table 2: Instrument and Statistical Tests

\begin{tabular}{|c|c|c|c|}
\hline No & Objectives & Instruments & $\begin{array}{c}\text { Statistical } \\
\text { Test }\end{array}$ \\
\hline 1 & $\begin{array}{l}\text { To examine the level of motivation, } \\
\text { Emotional intelligence, work } \\
\text { satisfaction and organizations } \\
\text { commitment among Islamic Education } \\
\text { teacher in primary school. }\end{array}$ & Questionnaires & $\begin{array}{c}\text { Mean \& } \\
\text { Standard } \\
\text { Deviation }\end{array}$ \\
\hline 2 & $\begin{array}{l}\text { To indicate the differences among } \\
\text { different gender and age groups of } \\
\text { Islamic Education teacher in primary } \\
\text { school concerning their motivation, } \\
\text { emotional intelligence, work } \\
\text { satisfaction and organizations } \\
\text { commitment. }\end{array}$ & Questionnaires & $\begin{array}{l}\text { t-test } \& \text { one- } \\
\text { way ANOVA }\end{array}$ \\
\hline 3 & $\begin{array}{l}\text { To identify the relationship between } \\
\text { motivation, emotional intelligence, } \\
\text { work satisfaction and organizations } \\
\text { commitment among Islamic Education } \\
\text { teacher in primary school. }\end{array}$ & Questionnaires & $\begin{array}{c}\text { Pearson } \\
\text { product } \\
\text { moment } \\
\text { correlation }\end{array}$ \\
\hline
\end{tabular}

\section{Results}

\section{Level of Motivation, Emotional Intelligence, Work Satisfaction and Organizations}

\section{Commitment}

Based on the table 3, Motivation, Emotional Intelligence, Work Satisfaction and Organizations Commitment were at a high level.

Table 3: Level of Motivation, Emotional Intelligence, Work Satisfaction and Organizations Commitment

\begin{tabular}{lccl}
\hline \multicolumn{1}{c}{ Scale } & Mean & SD & Level \\
\hline Motivation & 3.8591 & .42591 & High \\
& & & \\
Emotional Intelligence & 4.0866 & .28473 & High \\
Work Satisfaction & 4.3205 & .28473 & High \\
Organizations & 4.3198 & .22169 & High \\
Commitment & & & \\
\hline
\end{tabular}


Differences Among Different Gender And Age Groups Of Islamic Education Teacher In Primary School Concerning Their Motivation, Emotional Intelligence, Work Satisfaction And Organizations Commitment

T-Test resulted no significant difference among participants with different gender concerning their motivation, emotional intelligence and work satisfaction. (Table 4).

Table 4: T-Test Analysis

\begin{tabular}{lllcccc}
\hline & Gender & N & Mean & $\begin{array}{c}\text { Std. } \\
\text { Deviation }\end{array}$ & t & Sig \\
\hline Motivation & Male & 47 & 4.12 & 0.334 & 0.514 & 0.862 \\
& Female & 61 & 4.11 & 0.323 & & \\
Emotional & Male & 47 & 4.16 & 0.336 & .482 & 0.691 \\
Intelligence & Female & 61 & 4.13 & 0.320 & & \\
Work & Male & 47 & 4.16 & 0.331 & .465 & .811 \\
Satisfaction & Female & 61 & 4.13 & 0.324 & & \\
\hline
\end{tabular}

One way ANOVA resulted no significant difference among participants with different age concerning their motivation, emotional intelligence and work satisfaction.

Table 5: ANOVA Analysis

\begin{tabular}{lccccc}
\hline Motivation & $\begin{array}{c}\text { Sum of } \\
\text { Squares }\end{array}$ & df & $\begin{array}{c}\text { Mean } \\
\text { Square }\end{array}$ & F & Sig. \\
\hline Between Groups & .397 & 3 & .132 & 1.249 & .296 \\
Within Groups & 11.020 & 104 & .106 & & \\
Total & 11.417 & 107 & & & \\
\hline Emotional & & & & 1.663 & .180 \\
Intelligence & & & & & \\
\hline Between Groups & .519 & 3 & .173 & & \\
Within Groups & 10.825 & 104 & .104 & & \\
Total & 11.344 & 107 & & & \\
\hline Work Satisfaction. & & & & & \\
\hline Between Groups & .589 & 3 & .196 & & \\
Within Groups & 10.771 & 104 & .104 & & \\
Total & 11.360 & 107 & & & \\
\hline
\end{tabular}

Relationship Between Motivation, Emotional Intelligence, Work Satisfaction And Organizations Towards Commitment Among Islamic Education Teacher In Primary School. Regression analysis shows there was a significant strong positive relationship between Motivation, emotional intelligence and work satisfaction and organizations commitment among Islamic Education teacher in primary school (Table 6). 
Table 6: Correlation Between Variables Of The Study

Organizations Commitment

\begin{tabular}{ll}
\hline Motivation & $.905^{* *}$ \\
Emotional Intelligence & $.912^{* *}$ \\
Work Satisfaction & $.913^{* *}$ \\
\hline $\mathrm{N}=108$ & \\
$* *$ Correlation is significant at the 0.01 level (2-tailed).
\end{tabular}

\title{
Discussion and Conclusion
}

\begin{abstract}
Motivation
This study showed that teachers motivation is high, and this finding is consistent with others studies (Fei \& Han, 2017; Vinathan, 2017). However, this finding contrasts with the findings of Nik Badrul Hisham and Mastura (2015), who found that teachers' motivation level was at a moderate level. Male teachers are also found to have a similar level of motivation to female teachers. This finding was supported by Mahdi, Mat Isa and Md Johan (2005) in a study which stated that there were no significant differences between demographic factors namely age, gender, marital status and the duration of service on work motivation. Studies have also found that factors of work attitude, supervision and relationships with colleagues have a strong influence on work motivation. There is no significant difference in motivation based on age. This result is consistent with the findings of Mohd. Nor Jaafar (2004), where motivation is simply a set of influences or powers that a person may be interested in, leading to good achievement and influencing one's attitude and especially to employees in the pursuit of tasks and responsibilities given to them or required by management regardless of age factor as one aspect that is capable of changing one's motivation. Meanwhile, Zairul Hisyam (2014), consistently found that only attitude and training factors influence the motivation of an individual.
\end{abstract}

There is a high positive relationship between motivation and organizational commitment. This finding is in line with the results of Wan Noraini and Nooraini (2011). This study was also supported by Zairul Hisyam (2014), who found that attitude, training and motivation factors were also significantly associated with job performance. Clearly that motivation can influence a teacher's organizational commitment. When teachers are rewarded for their work, it increases their motivation to work. This indirectly affects the level of teacher commitment to the organization when performing tasks. In other words, motivation can improve teachers' performance by actively engaging them in their work and becoming excellent employees and having high levels of commitment to their organization. Motivation can be acquired intrinsically and extrinsically. Intrinsic motivation relates to the motivation to do something under any circumstances. Intrinsic motivation is generated from the sense of personal satisfaction that exists within the individual. Motivation can be manipulated by unpleasant situations or situations that may encourage individuals to explore better situations. In fact, individuals are motivated when they have the constraints to get something they want or need in life. A person's high motivation can increase his or her commitment to the task, be positive about change, be more creative in performing the task and improve overall performance (Eyal and Roth, 2011). For example, highly motivated teachers will continue to look for ways or improve their teaching skills to produce more successful students. 


\section{Emotional Intelligence}

The results showed that the interpretation of the mean scores for empathy dimensions, social skills, self-awareness and self-management were high. On the other hand, the mean score for the motivational dimension was moderate. This finding is supported by the findings of Muhammad Idhan et al (2010). The analysis showed that there was no difference in emotional intelligence based on the gender of the teacher. This is consistent with the findings of Goleman (1998b) in his study that found that male and female subjects are equally capable of enhancing and managing their own emotions. Male and female also have the same ability to increase their level of intelligence. Local studies by Yahaya and Donna (2001) do not show differences in gender-based emotional intelligence. This finding was supported by Lim Tze Shin (2011) who stated that there were no significant differences in emotional intelligence between the subjects of the male and female studies. According to the theory presented by Bar-On (1997), there are many similarities in emotional intelligence between male and female or in other words there is no gender difference in relation to emotional intelligence. Factors that may influence this local study are cultural factors rather than gender factors. However, there are also previous studies that contradict the findings of this study. The findings of a study by Florence (2007) found that emotional intelligence among male and female teachers revealed significant differences. There is no differences in emotional intelligence based on age. The results of the analysis showed that there were no differences in emotional intelligence based on age. This is because most of the survey respondents are from young teachers. Only 11 respondents aged 50 years and above. Possible contributing factors are the lack of teachers over 50 who answer the questionnaire provided.

The findings show that there is a correlation between emotional intelligence and the commitment of Islamic education teacher organizations in Ranau district. These results prove that the higher the emotional intelligence, the higher the commitment of one's organization to the work involved. The findings of this study directly support and are in line with the findings of Norhafeza and Ferlis (2010) who conducted studies on the relationship between emotional intelligence, job satisfaction and organizational commitment. The findings show that emotional intelligence is positively and positively related to organizational commitment. The elements of emotional intelligence and job satisfaction can be considered as the core of building an individual's work performance, as well as quality. (Iskandar, Rohaty \& Zuria, 2009). For the academic profession, emotional intelligence is a personality trait that every teacher needs to have in order to succeed in his or her career. From the findings of this study, it was found that emotional intelligence can assist teachers in assessing self-efficacy, thus catalysing the improvement of human resource quality and this is also supported by Iskandar et. al (2009).

\section{Work Satisfaction}

Based on the analysis of the mean scores for job satisfaction, only the promotion dimension is at a moderate level. The other five dimensions are at high level. Lee (2010) study showed that the level of job satisfaction of teachers in the national secondary school in Sandakan district showed that the results were moderate. This is contrary to the findings of Nadiah and Azlin (2014) who found that the level of satisfaction of SMK teachers is higher than teachers in SBP and SMKA. There was no significant difference in teacher job satisfaction between male and female teachers. This finding is supported by Siti Rokiah (2013) in her study showed that there was no significant difference in teacher job satisfaction based on demographic factors namely gender. Formation of job satisfaction has nothing to do with gender factors (Baron \& Byrne, 2000). This finding also supports Maslow's hierarchical theory of needs. The theory states that individuals are never satisfied with what has been achieved. This theory emphasizes that as individuals and organizations grow, the needs of individuals also change. This means that 
teacher satisfaction depends on the degree to which the basic needs have been met and not on the individual's gender. As such, male and female teachers who teach Islamic education in Ranau district believe that the demands of the job they receive will be commensurate. There is no difference in the mean of job satisfaction of Islamic education teachers in Ranau district based on age. The findings of this study were supported by Ismail (1997) who looked at demographic factors such as gender, academic status, age and experience of job satisfaction of Grade A primary school teachers in Kuala Muda, Yan. The findings show that there is no significant difference between the demographic factors selected for job satisfaction. The results of Noraishah (2010) study also show that there is a significant difference in job satisfaction by age. This means that job satisfaction experienced by employees of different ages is significantly different. According to him, finding one's age can determine the worker's satisfaction. Older employees are more likely to work compared to younger workers. This finding is in line with Junaidah and Nik Rosila, (2013) which found that there were no significant differences in mean job satisfaction based on factors of remuneration, assignments and work environment by gender, duration of teaching experience and highest approval of special education among teachers special education.

The findings of this study show that there is a significant relationship between job satisfaction and commitment of Islamic education teacher organizations in Ranau district. This shows that the higher the job satisfaction, the higher the teacher's commitment to the organization. The findings of this study are in line with a study conducted by Nahid (2012) who studied emotional intelligence, job satisfaction and organizational commitment among English-speaking high school teachers in Iran. The findings show that there is a significant positive relationship between emotional intelligence and job satisfaction, emotional intelligence and organizational commitment. According to Mohd Shaladdin Muda and Nik Wan Omar (2006), the study found that most of the factors determining job satisfaction were working time, teacher and pupil welfare, bureaucracy, promotion, facilities, and teacher duties at the level of satisfaction. low. However, human satisfaction is neither natural nor natural. Some individuals want success for success, while other individuals find it easy to be satisfied with what they already have (Ainon \& Abdullah, 2011).

\section{Research Implication}

To ensure that the level of organizational commitment among teachers increases and works well, here are some suggestions that can be applied by administrators or organizations;

a) Teachers have different attitudes and behaviours so administrators should know how to ensure their needs, each individual's needs can be met in order to continue to provide high commitment to the organization.

b) The administrator must provide an incentive or award of a fair and equitable service award to ensure that qualified teachers or workers are rewarded for their efforts/work. This will indirectly increase the individual's commitment to his or her organization.

c) The organization needs to identify and ensure that the basic needs of each employee are met. Understand the problems experienced by teachers and take care of organizational issues well and prudently.

\section{References}

Ainon Mohd dan Abdullah Hassan (2011). 11 Teori dan Prinsip Motivasi di Tempat Kerja. PTS Profesional Publishing Sdn. Bhd.

Baharin Bin Abu \& Hamiza Binti Mohd Salleh @ Yaakob (2018). Faktor-faktor mendorong stres dalam kalangan guru-guru yang mengikuti Program Khas Pensiswazahan Guru (PKPG) Sepenuh Masa, Fakulti Pendidikan, Universiti Teknologi Malaysia. 
Bai, N., Piri, R., \& Piri, A. (2014). Investigating school organization climate and job satisfaction from Kalale physical education teachers' point of view. Research Journal of Sport Science, 2(2),45-49

Bar-On, R. (1997a). The Emotional Quotient Inventory(EQ-i): A test of emotional intelligence. Toronto, Canada: Multi-Health Systems, Inc.

Baron \& Byrne. (2000). Social Psychology. (9th Edition). Massachusetts: A Pearson Education Company.

Baron, R.A \& Greenberg, J. (1990). Behaviour In Organisation: Understanding And Managing The Human Slide Work. (3rd edition). Boston: Allyn Bacon.

Chua, B.S. \& Adi Fahruddin (2002). Tekanan Pekerjaan, kepuasan kerja dan implikasinya terhadap proses pengajaran-pembelajaran di sekolah: satu kajian ke atas guru-guru sekolah menengah di Kota Kinabalu, Sabah. Prosiding Seminar Kebangsaan Profesion Perguruan 2002: 198-207

Eyal, O. \& Roth, G. (2011). Principals' Leadership and Teachers' Motivation: Self Determination Theory Analysis. Journal of Educational Administration. 49(3): 256275

Fei, E. L. E., \& Han, C. G. K. (2017). Hubungan Iklim Sekolah Dengan Motivasi Guru. Jurnal Pemikir Pendidikan, 8, 43-68.

Florence Fletcher (2007). Hubungan tahap kecerdasan emosi dengan tahap kepuasan kerja dan tahap komitmen kerja di kalangan guru bimbingan dan kaunseling sekolah menengah di Bandaraya Kuching, Sarawak. Tesis Sarjana. Skudai: Universiti Teknologi Malaysia

Goleman, D. (1998a). What makes a leader? Harvard Business Review, 76(6):93-103

Goleman, D. (1998b). Working with emotional intelligence. New York: Bantam Books.

Iskandar, Rohaty Mohd. Majzub \& Zuria Mahmud. (2009). Kecerdasan emosi dan komitmen pekerjaan dalam kalangan pensyarah universiti Indonesi. Jurnal Pendidikan Malaysia. 34(1):173-186.

Ismail Bin Othman. 1997. Kepuasan Kerja di Kalangan Guru-guru Sekolah Rendah Gred A Daerah Kuala Muda Yan. Tesis Sarjana. Universiti Utara Malaysia.

Junaidah Mohamad \& Nik Rosila Nik Yaacob. 2013. Kajian tentang kepuasan bekerja dalam kalangan guru-guru pendidikan khas. Asia Pacific Journal of Educators and Education 28: 102-115.

Jackson, M. J. (2018). Examining the Relationship between School Climate and Teacher Absenteeism, Teacher Job Satisfaction, and Teachers' Intentions to Remain. Trevecca Nazarene University.

Kementerian Pendidikan Malaysia (2013). Pelan Pembangunan Pendidikan Malaysia 2013-2025. https://www.moe.gov.my/menumedia/media-cetak/penerbitan/1813pppm-2 013-2025/file

Lee Fung Chuen (2010). Pengaruh Pengupayaan Guru dan Kepuasan Kerja Terhadap Komitmen Organisasi Dalam Kalangan Guru Sekolah Menengah Kebangsaan Di Daerah Sandakan, Sabah. Sekolah Pendidikan dan Pembangunan Sosial. Universiti Malaysia Sabah.

Lim, T. S (2011) Gender differences in emotional intelligence: are you smart as you think emotionally. Final Year Project, UTAR.

Madhu G. \& Manju G. (2013). A study of the Correlates of Organizational Commitment Among Secondary School Teachers. Issues and Ideas in Education. 1:59-71)

Mahdi, Mat Isa \& Md Johan, Othman (2005). Tahap Motivasi Kerja Di Kalangan Kakitangan Yayasan Pembangunan Keluarga Darul Ta'zim. Tesis Master, Universiti Teknologi Malaysia. 
Mashaba, E. K., \& Maile, S. (2019). Factors underlying teacher absenteeism in selected schools located in Tshwane West District, South Africa. International Journal of Educational Development, 4(1), 1-24.

Mohd. Nor Jaafar (2004). Kepimpinan Pengajaran Guru Besar, Komitmen dan Kepuasan Kerja Guru: Satu Kajian Perbandingan dan Hubungan antara Sekolah Berkesan dengan sekolah Kurang Berkesan. Tesis Phd. Universiti Sains Malaysia.

Mohd Shaladdin Muda \& Nik Wan Omar (2006). Model peramal kepuasan kerja pegawai perkhidmatan pendidikan di komuniti pesisir Terengganu. International Journal of Management Studies (IJMS), 13. 123-142.

Muhammad Azmi Abdullah (1999). Hubungan Pelaksanaan Konsep Empowerment Dengan Komitmen Terhadap Organisasi: Satu Tinjauan Persepsi Guru. Universiti Sains Malaysia Pulau Pinang.

Muhammad Idhan, Zamri Mahmod, Melor Md. Yunus \& Nik Mohd Rahimi Nik Yusoff (2010). Profil keceerdasan emosi guru pelatih bahasa mengikut tahun pengajian. GEMA Online Journal of Language Studies 10(2):57-75.

Mukundan, J., \& Ahour, T. (2011). Burnout among female teachers in Malaysia. Journal of International Education Research (JIER), 7(3), 25-38.

Nadiah, M.A. \& Azlin Norhaini, M. (2014). Amalan kepimpinan transformational pengetua dan kepuasan kerja guru di Sekolah Menengah Agama Bantuan Kerajaan (SABK) Negeri Sembilan. International Seminar on Global Education II, UKM Bangi.

Nahid Naderi Anari (2012). Teacher: emotional intteligence, job satisfaction, and organizational commitment. Journal of Workplace Learning. 24(4):256 -269

Nik Badrul Hisham Bin Nik Ismail \& Mastura Mahfar. (2015). Hubungan Antara Gaya Kepimpinan Pengetua Dengan Motivasi Dalam Kalangan Guru SMK Harian Daerah Kluang, Johor. Sains Humanika, 1: 9-18.

Noraishah Daud (2010). Jaminan kerja dan hubungannya dengan kepuasan Kerja dan komitmen terhadap organisasi. international, Conference on Ethics and Professionalism 2010 (ICEP 2010), 474-491

Norhafeza Herliani Adey \& Ferlis Hj Bahari (2010). Hubungan antara kecerdasan emosi, kepuasan kerja dan komitmen terhadap organisasi. Jurnal Kemanusiaan. 16(Dec):6282

Nur Suhaila (2011). Hubungan antara Penilaian Prestasi dan Pengaruhnya Terhadap Komitmen Kerja Guru Di Sekolah-sekolah Sekitar Daerah Seberang Prai Utara, Pulau Pinang. Tesis Sarjana. Universiti Utara Malaysia.

Omar Abdul Kareem \& Khuan Wai Bing (2005). Perkembangan Profesional Guru Secara Berterusan: Perspektif Pembangunan Sumber Manusia. Majalah Pendidikan Universiti Malaya. 131-141

Siti Rokiah Kadir, (2013) Hubungan antara kepuasan kerja dengan motivasi guru sekolah menengah di daerah Sandakan. Master's thesis, Universiti Malaysia Sabah.

Surianshah, S. (2019). Household education expenditure, school effects, and teacher absenteeism in Malaysia. Doctoral dissertation, University of Nottingham.

Syafrimen Syafril (2004). Profil kecerdasan emosi guru-guru sekolah menengah Zon Tengah Semenanjung Malaysia. Master project paper. Universiti Kebangsaan Malaysia.

Syed Najmuddin Syed Hassan, Noriah Mohd. Ishak, Mohamad Bokhari (2011). Impact of emotional intelligence (EQ) on work values of high school teachers. Procedia-Social and Behavioral Science. 30(2011):1688-1692.

Vanderbilt University: Center For Teaching (2011). Motivating students. http://cft.vanderbilt.edu/teaching-guides/interactions/motivating-studente/

Vinathan, T. A. (2017). Hubungan motivasi guru dengan penggunaan ICT dalam pengajaran di SJK (T) daerah Kuala Muda Yan. Proceedings of the ICECRS, 1(1), 1043-1054. 
Wan Noraini Wan Razab dan Nooraini Othman. (2011). Tahap Motivasi dan Punca Tekanan Guru yang Melanjutkan Pengajian. Jurnal Kemanusiaan. 9(1)

Yahaya Mahmood \& Donna Ng Li Eng. (2001). Tahap dan peranan kecerdasan emosi (EQ) di kalangan pelajar-pelajar remaja di bangku sekolah. Jurnal Psikologi dan Pembangunan Manusia, 17: 35-58.

Yahzanon Tahir \& Yusof Boon (2011). Tahap kecerdasan Emosi dan Hubungannya dengan Komitmen Guru dalam Bekerja Dalam Kalangan Guru Mata Pelajaran Teras tahun Enam. Journal of Edupres. 1(2011): 187-196.

Zairul Hisyam, Abd Wahab (2014) Pengaruh faktor sikap, latihan dan motivasi ke atas prestasi kerja kajian di Bahagian Penganjuran Pelajaran MARA. Masters thesis, Universiti Utara Malaysia. 